\title{
РЕГИОНАЛЬНОЕ РАЗВИТИЕ
}

УДК 911.9; 332.02

\section{ГЕОГРАФИЯ ОСОБЫХ ЭКОНОМИЧЕСКИХ ЗОН И ИХ АНААОГОВ В РОССИИ}

\author{
(C) 2020 г. О.В. Кузнецова ${ }^{1,2,3}$ \\ ${ }^{1}$ Федеральный исследовательский иеентр «Информатика и управление» \\ Российской академии наук, Москва, Россия \\ ${ }^{2}$ Российский экономический университет имени Г.В. Плеханова, Москва, Россия \\ ${ }^{3}$ Московский государственный университет имени М.В. Ломоносова, \\ географический факультет, Москва, Россия \\ e-mail: kouznetsova_olga@mail.ru
}

\begin{abstract}
В статье предлагается использовать подход ЮНКТАД к выделению особых экономических зон (ОЭЗ), в соответствии с которым ОЭЗ могут считаться образования, отвечающие трем критериям: четко определенные границы территории зоны, отличный от общенационального режим регулирования хозяйственной деятельности, развитая инфраструктура. В статье анализируется сложившаяся в России география ОЭЗ в таком широком их понимании. Делается вывод о неоправданной сложности российской системы ОЭЗ и их аналогов и предлагается создать полноценную государственную информационную систему по территориям с преференциальными режимами для инвесторов и повысить единообразие действующих режимов. Показано, что в настоящее время преференциальные режимы способствуют социально-экономическому развитию приоритетных геостратегических территорий (за исключением Северного Кавказа), но за их пределами скорее способствуют росту межрегиональных различий в уровне социальноэкономического развития, нежели их сокращению. Предлагается не отказываться от создания ОЭЗ и их аналогов в проблемных регионах, но предоставлять инвесторам достаточные по своей благоприятности условия и дифференцированно подходить к оценке эффективности ОЭЗ и их аналогов в регионах с объективно разным уровнем инвестиционной привлекательности.
\end{abstract}

Ключевые слова: преференциальный режим, особые экономические зоны, территории опережающего развития, геостратегические территории, моногорода, инвестиционная политика, региональная политика.

DOI: $10.5922 / 1994-5280-2020-4-2$

Введение и постановка проблемы. Федеральная экономическая политика является одним из важных факторов размещения различных видов деятельности. Далеко не всегда ее влияние поддается оценке, особенно в случае принятия общих для всей территории страны решений. Но есть составляющие в государственной политике, прямо нацеленные на привлечение инвесторов в отдельные регионы, муниципальные образования или даже на небольшие по своим размерам площадки. Речь идет о так называемых преференциальных режимах ведения хозяй- ственной деятельности, подразумевающих создание льготных условий для инвесторов в границах определенной территории.

Доминирование в течение довольно длительного периода в России либеральных взглядов на государственное регулирование экономики не способствовало созданию таких преференциальных режимов. Вплоть до начавшегося в конце 2008 г. кризиса были лишь немногочисленные исключения в виде особых экономических зон (ОЭЗ) - созданных отдельными федеральными решениями в Калининградской и Магаданской областях, 
а также в соответствии с федеральным законом 2005 г. «Об особых экономических зонах в Российской Федерации». Несмотря на принятие такого общего закона об ОЭЗ, создано их было очень немного, при этом собственно производственных - только две, представленных компактными производственными площадками на территорию огромной страны. В 2000-е годы условия для экономического роста складывались и без активной федеральной инвестиционной политики, масштабы региональной политики были явно недостаточными, что многократно подвергалось критике со стороны экспертного сообщества.

Ситуация кардинально поменялась в 2010-е годы, когда экономический кризис, дополненный введенными в 2014 г. экономическими санкциями, заставил федеральные власти активнее работать над созданием условий для привлечения инвестиций в регионы. Это было обусловлено как необходимостью поиска источников экономического роста в стране в целом, так и обострением проблем социально-экономического развития ряда территорий (в том числе моногородов, о поддержке которых на федеральном уровне всерьез заговорили именно в кризис 2009 г.). В дополнение к ОЭЗ был создан еще целый ряд преференциальных режимов (включая территории опережающего социально-экономического развития), и в итоге разных вариантов ОЭЗ и их аналогов оказалось около десятка.

Такую ситуацию нельзя назвать благополучной, хотя бы в силу чрезмерной сложности и запутанности для инвесторов системы их поддержки: преференциальные режимы существуют во многом каждый сам по себе, в единую систему они не выстроены. Нет и общей логики отбора территорий, где вводятся различные преференциальные режимы. Следовательно, оказывается неочевидным влияние таких режимов на сокращение межрегиональных диспропорций; масштабы вводимых для инвесторов преференций в отдельных регионах могут оказываться недостаточными для повышения их конкурентоспособности; может возникать неоправданная конкуренция между самими преференциальными режимами.

Цель данной статьи - оценить существующий опыт внедрения преференциальных режимов (ранее в полном объеме такая оценка не проводилась); проанализировать принципы отбора территорий для внедрения таких режимов и фактически сложившуюся географию ОЭЗ и их аналогов; объяснить причины сложившейся ситуации и предложить возможные варианты дальнейших действий в рамках федеральной экономической политики. При этом особое внимание уделяется оценке возможного вклада ОЭЗ и их аналогов в решение задачи сокращения территориальных диспропорций в уровне социально-экономического развития.

Обзор ранее выполненных исследований. Создаваемые в России ОЭЗ и их аналоги, конечно, привлекают немало внимания со стороны исследователей. Часто в научных работах анализируются особенности отдельных типов территорий с преференциальными режимами хозяйственной деятельности, например, ОЭЗ в Калининградской области [20; 22], ОЭЗ в Магаданской области [12], свободной экономической зоны в Крыму [16], Свободного порта Владивосток [1].

Обращались исследователи и к сравнению разных преференциальных режимов, начиная с сопоставления ОЭЗ 2000-х годов [15]. Создание разнообразных аналогов ОЭЗ в 2010-е годы привело к появлению исследований по группам преференциальных режимов: собственно ОЭЗ стали сравнивать c территориями опережающего социально-экономического развития (ТОСЭР) [17], a ТОСЭР на Дальнем Востоке - со Свободным портом Владивосток [8; 14].

В целом ряде работ анализируются инструменты поддержки инвесторов (причем не только ОЭЗ или их аналоги) с точки зрения их роли в развитии отдельных секторов экономики. Чаще всего речь идет о высокотехнологичной или инновационной деятельности [2; 3; 7], но есть и иные примеры - по минерально-сырьевым проектам [10], промышленным кластерам [11]. В ряде исследований проводилось сравнение разнообразных преференциальных режимов [5; 11], однако, повторимся, в них не ставилась задача анализа размещения территорий c преференциальными инвестиционными режимами. Кроме того, в последние годы федеральное законодательство в рассматриваемой сфере активно развивается, например, весьма значимое решение по господдержке предпринимательской деятельности 
в Арктической зоне РФ было утверждено только летом 2020 г.

Отметим наиболее значимые из полученных ранее выводов с точки зрения цели данной статьи:

- создание ОЭЗ или их аналогов для решения задач региональной политики в проблемных регионах ради сокращения их отставания от регионов-лидеров - это лишь одна из возможных целей использования преференциальных налоговых режимов в рамках государственного регулирования экономики. ОЭЗ часто используются в качестве инструмента инвестиционной политики (увеличения инвестиционной привлекательности страны в целом), для обеспечения прогрессивных изменений в структуре экономики стран [21; 23];

- оправданность названного подхода подтверждается и уже имеющимся опытом создания российских ОЭЗ: они оказались более успешными в регионах, изначально имевших более высокую инвестиционную привлекательность в силу более выгодного экономико-географического положения, наличия благополучных предприятий (с которыми резиденты ОЭЗ могут выстраивать технологические цепочки, благодаря которым сформировалась система подготовки кадров) [6; 19];

- множественность преференциальных режимов инвестиционной деятельности, действительно, является проблемой для предпринимателей, которые говорят о недостаточной информированности о действующих мерах их поддержки [9].

Материалы и методика исследования. Предлагаемое в данной статье совместное рассмотрение ОЭЗ и по-иному называемых территорий с преференциальными режимами не является исключительно российской практикой. В 2019 г. специальной темой доклада ЮНКТАД о мировых инвестициях [23] стали особые экономические зоны, и при подготовке этого доклада эксперты ЮНКТАД предложили считать ОЭЗ не только те территории, которые именно так называются (special economic zones), но и отвечающие определенным критериям.
При этом формально такие территории могут быть свободными экономическими зонами (free economic zones), индустриальными парками (industrial parks), зонами экономического/промышленного развития (есоnomic/ industrial development zones) и т.д. Критериев для выделения ОЭЗ предложено три (выполняться они должны одновременно):

- четко определенные границы территории зоны;

- отличный от общенационального режим регулирования хозяйственной деятельности, чаще всего включающий в себя таможенные и налоговые льготы; могут также быть особые правила в отношении иностранной собственности, земельного и трудового законодательства;

- поддержка развития инфраструктуры.

Последний критерий, в отличие от двух первых, является не очень четким. Когда речь идет о компактных ОЭЗ - специально выделенных под них площадках размером в несколько квадратных километров, то вполне очевидна необходимость разработки и реализации специальных программ развития инфраструктуры ОЭЗ. Если же ОЭЗ занимает обширные территории, будучи созданной в границах всей административно-территориального единицы (АТЕ) или даже нескольких единиц (в терминологии ЮНКТАД wide-area zones), то поддержка развития инфраструктуры может осуществляться в рамках общих программ развития таких АТЕ. Но даже если ОЭЗ занимает компактный участок территории, то не исключена ситуация, когда можно обойтись без вложений из бюджета центрального правительства в инфраструктуру (например, к моменту создания ОЭЗ необходимая инвесторам инфраструктура уже существует).

Создание ОЭЗ требует также формирования специальной структуры для ее управления, однако к формату такой структуры жестких требований тоже не выдвигается - т.е. должна ли это быть управляющая компания или же достаточно отдельного подразделения в органах власти.

Предложенный ЮНКТАД подход к трактовке понятия ОЭЗ не является единственно возможным, позиции отдельных экспертов могут отличаться [18], но в данной статье мы будем придерживаться именно подхода ЮНКТАД и рассмотрим преференциаль- 
ные режимы, отвечающие трем названным критериям (четко определенная территория, наличие льгот инвесторам и поддержка инфраструктуры).

Основным источником информации для нашего исследования являются базы данных российских нормативно-правовых актов (использовались данные компании «КонсультантПлюс»), в том числе по созданию отдельных ОЭЗ или их аналогов.

Подчеркнем, что в статье речь идет о тех решениях, которые приняты только на федеральном уровне. Существуют еще ОЭЗ и их аналоги, созданные решениями региональных органов власти. Они являются еще одной иллюстрацией чрезмерной сложности системы поддержки инвесторов в России, но их наличие не существенно для решения одной из основных задач данной статьи оценить возможный вклад преференциальных режимов в снижение территориальных диспропорций. Перед нами не стояла также задача детального рассмотрения каждого из преференциальных режимов, так как это было сделано в указанных выше научных публикациях.

Полученные результаты. Проведенный нами анализ федерального законодательства показывает, что особыми экономическими зонами в понимании ЮНКТАД в России являются:

- собственно ОЭЗ четырех типов (промышленно-производственные, технико-внедренческие, туристско-рекреационные, портовые), созданные на основе Федерального закона от 22.07.2005 № 116-Ф3 «Об особых экономических зонах в Российской Федерации», а также в соответствии с отдельными федеральными законами в Калининградской и Магаданской областях (федеральные законы от 10.01.2006 № 16-ФЗ и от 31.05.1999 № 104-Ф3 соответственно);

- свободная экономическая зона в Крыму - Республике Крым и г. Севастополе (Федеральный закон от 29.11.2014 № 377-Ф3);

- территории опережающего социально-экономического развития (Федеральный закон от 29.12.2014 № 473Ф3) и Свободный порт Владивосток (Федеральный закон от 13.07.2015
№ 212-Ф3), которые объединяет то, что оба закона начали разрабатывать для поддержки Дальнего Востока, но в процессе принятия закона о ТОСЭР его распространили и на моногорода;

- инновационный центр «Сколково» и инновационные научно-технологические центры (федеральные законы от 28.09.2010 № 244-ФЗ и от 29.07.2017 № 216-ФЗ соответственно);

- Арктическая зона РФ, на всей территории которой введен преференциальный режим для инвесторов (Федеральный закон от 13.07.2020 № 193-Ф3).

В данный список не попали наукограды, индустриальные парки, технопарки в сфере высоких технологий, инновационные территориальные кластеры, поскольку в федеральном законодательстве не предусматриваются налоговые льготы, привязанные именно к этим территориальным образованиям (что не исключает возможности использования работающими в них предпринимателями налоговых льгот, предусмотренных для тех или иных видов деятельности федеральным законодательством или законодательством субъектов РФ).

Необходимо еще упомянуть Федеральный закон от 03.12.2011 № 392-Ф3 «О зонах территориального развития в Российской Федерации...». По своему замыслу зоны территориального развития могли бы стать одной из разновидностей ОЭЗ [13; 17], однако закон до сих пор реально не заработал. Формально он не утратил силу, более того, в конце декабря 2019 г. правительственным постановлением был обновлен перечень субъектов РФ, где могут создаваться зоны территориального развития (таких субъектов РФ 20 - самых проблемных). Но нет ни решений по созданию таких зон, ни внесенных в Налоговый кодекс РФ поправок о налоговых льготах их резидентам.

Названные федеральные законы можно разделить на две группы. Одна группа - законы, в которых непосредственно определяются границы территорий с преференциальными режимами. Это закон об ОЭЗ в Калининградской и Магаданской областях, СЭЗ в Крыму, инновационному центру «Сколково», Арктической зоне РФ и Свободному порту Владивосток (СПВ). Правда, у последнего закона есть одна особенность: в него вносились поправки, которыми рас- 
ширялись границы действия данного преференциального режима, и теперь название СПВ является очень условным, поскольку этот режим распространяется на 5 дальневосточных субъектов РФ (см. табл. 1).

Вторая группа законов - в которых конкретные территории с преференциальными режимами не определяются, таковые соз- даются отдельно принимаемыми постановлениями Правительства РФ. Это законы об ОЭЗ, ТОСЭР и ИНТЦ (инновационных научно-технологических центрах). Причем процесс принятия решений о создании таких территорий с преференциальными режимами продолжается вплоть до настоящего времени, т.е. его нельзя считать завершенным.

Таблица 1. Действующие в России ОЭЗ и их аналоги (на декабрь 2020 г.)

\begin{tabular}{|c|c|}
\hline Субъект РФ & Действующие на территории субъектов РФ ОЭЗ и их аналоги \\
\hline \multicolumn{2}{|c|}{ Центральный федеральный округ } \\
\hline Белгородская область & ТОР «Губкин» \\
\hline Брянская область & - \\
\hline Владимирская область & ОЭЗ ППТ «Доброград-1» (Ковровский р-н) ТОР «Камешково» \\
\hline Воронежская область & ОЭЗ ППТ «Центр» (Новоусманский р-н) \\
\hline Ивановская область & ТОР «Наловолоки», ТОР «Южа» \\
\hline Калужская область & $\begin{array}{l}\text { ОЭЗ ППТ «Калуга» (Людиново, Людиновский и Боровский } \\
\text { р-ны) ТОР «Кондрово», ТОР «Сосенский» }\end{array}$ \\
\hline Костромская область & ТОР «Галич» \\
\hline Курская область & - \\
\hline Липецкая область & ОЭЗ ППТ «Липецк» (Грязинский и Елецкий р-ны) \\
\hline Московская область & $\begin{array}{l}\text { ОЭЗ ППТ «Максимиха» (Домодедово), ОЭЗ ППТ «Кашира», } \\
\text { ОЭЗ ППТ «Ступино Квадрат» (Ступинский р-н), ОЭЗ ТВТ } \\
\text { «Дубна», ОЭЗ ТВТ «Исток» (Фрязино) }\end{array}$ \\
\hline Орловская область & ОЭЗ ППТ «Орел» (Мценский р-н) ТОР «Мценск» \\
\hline Рязанская область & ТОР «Лесной» \\
\hline Смоленская область & TOP «Дорогобуж» \\
\hline Тамбовская область & ТОР «Котовск» \\
\hline Тверская область & ОЭЗ ТРТ «Завидово» (Конаковский р-н) ТОР «Кувшиново» \\
\hline Тульская область & ОЭЗ ППТ в Узловском р-не ТОР «Алексин», ТОР «Ефремов» \\
\hline Ярославская область & ТОР «Гаврилов Ям», ТОР «Ростов», ТОР «Тутаев» \\
\hline г. Москва & $\begin{array}{l}\text { ОЭЗ ТВТ «Технополис «Москва», инновационный центр } \\
\text { «Сколково», ИНТЦ МГУ «Воробьевы горы», ИНТЦ «Долина } \\
\text { Менделеева» }\end{array}$ \\
\hline \multicolumn{2}{|c|}{ Северо-Западный феедеральный округ } \\
\hline Республика Карелия & $\begin{array}{l}\text { Арктическая зона (Костомукша, Беломорский, Калеваль- } \\
\text { ский Кемский, Лоухский Сегежский р-ны), ТОР «Кондопога», } \\
\text { TOP «Костомукша», ТОР «Надвоицы» }\end{array}$ \\
\hline Республика Коми & $\begin{array}{l}\text { Арктическая зона (Воркута, Инта, Усинск, Усть-Цилемский } \\
\text { р-н), ТОР «Емва» }\end{array}$ \\
\hline Архангельская область & $\begin{array}{l}\text { Арктическая зона (Архангельск, Новая Земля, Новодвинск, } \\
\text { Северодвинск, Мезенский, Онежский, Приморский, Лешукон- } \\
\text { ский, Пинежский р-ны), ТОР «Онега» }\end{array}$ \\
\hline Ненецкий АО & Арктическая зона (вся территория) \\
\hline Вологодская область & ТОР «Череповец» \\
\hline Калининградская область & ОЭЗ на территории всей области \\
\hline Ленинградская область & TOP «Пикалево» \\
\hline Мурманская область & $\begin{array}{l}\text { Арктическая зона (вся территория), ТОР «Столица Арктики» } \\
\text { (г. Мурманск и Кольский район), ТОР «Кировск» }\end{array}$ \\
\hline Новгородская область & TOP «Боровичи», ТОР «Угловка» \\
\hline Псковская область & ОЭЗ ППТ «Моглино» (Псковский р-н) \\
\hline г. Санкт Петербург & ОЭЗ ТВТ «Санкт-Петербург» \\
\hline \multicolumn{2}{|l|}{ Южный фредеральный округ } \\
\hline Республика Адыгея & - \\
\hline Республика Калмыкия & - \\
\hline
\end{tabular}


Таблица 1. Продолжение

\begin{tabular}{|c|c|}
\hline Субъект РФ & Действующие на территории субъектов РФ ОЭЗ и их аналоги \\
\hline Республика Крым & Свободная экономическая зона на территории всего региона \\
\hline Краснодарский край & ИНТЦ «Сириус» (Сочи) \\
\hline Астраханская область & $\begin{array}{l}\text { Каспийский кластер: ОЭЗ ППТ «Лотос» (Наримановский р-н) и } \\
\text { ПОЭЗ «Оля» (Лиманский р-н) }\end{array}$ \\
\hline Волгоградская область & ТОР «Михайловка» \\
\hline Ростовская область & ТОР «Гуково», ТОР «Донецк», ТОР «Зверево» \\
\hline г. Севастополь & Свободная экономическая зона на территории всего региона \\
\hline \multicolumn{2}{|c|}{ Северо-Кавказский фредеральный округ } \\
\hline Республика Дагестан & $\begin{array}{l}\text { ОЭЗ ТРТ «Матлас» (Прибрежный кластер из } 5 \text { р-нов) } \\
\text { ТОР «Дагестанские Огни», ТОР «Каспийск» }\end{array}$ \\
\hline Республика Ингушетия & $\begin{array}{l}\text { ОЭЗ ТРТ «Армхи» и «Цори» (Джейрахский и Сунженский } \\
\text { р-ны) }\end{array}$ \\
\hline $\begin{array}{l}\text { Кабардино-Балкарская Респу- } \\
\text { блика }\end{array}$ & ОЭЗ ТРТ «Эльбрус» (Эльбрусский и Зольский р-ны) \\
\hline $\begin{array}{l}\text { Карачаево-Черкесская Респу- } \\
\text { блика }\end{array}$ & ОЭЗ ТРТ «Архыз» (Зеленчукский и Урупский р-ны) \\
\hline $\begin{array}{l}\text { Ресублика Северная Осетия- } \\
\text { Алания }\end{array}$ & ОЭЗ ТРТ «Мамисон» (Алагирский р-н) \\
\hline Чеченская Республика & $\begin{array}{l}\text { ОЭЗ ППТ «Грозный», ОЭЗ ТРТ «Ведучи» (Итум-Калинский } \\
\text { р-н) }\end{array}$ \\
\hline Ставропольский край & ТОР «Невинномысск» \\
\hline \multicolumn{2}{|c|}{ Приволжский фредеральный округ } \\
\hline Республика Башкортостан & $\begin{array}{l}\text { ОЭЗ ППТ «Алга» (Ишимбайский и Стерлитамакский р-ны) } \\
\text { TOP «Белорецк», ТОР «Благовещенск», ТОР «Кумертау», } \\
\text { TOP «Нефтекамск» }\end{array}$ \\
\hline Республика Марий Эл & - \\
\hline Республика Мордовия & ТОР «Рузаевка» \\
\hline Республика Татарстан & $\begin{array}{l}\text { ОЭЗ ППТ «Алабуга» (Елабужский р-н), ОЭЗ ТВТ «Иннополис» } \\
\text { (Верхнеуслонский и Лаишевский р-ны) ТОР «Зеленодольск», } \\
\text { ТОР «Менделеевск», ТОР «Набережные Челны», ТОР «Ниж- } \\
\text { некамск», ТОР «Чистополь» }\end{array}$ \\
\hline Удмуртская Республика & ТОР «Глазов», ТОР «Сарапул» \\
\hline Чувашская Республика & ТОР «Канаш» \\
\hline Пермский край & ТОР «Нытва», ТОР «Чусовой» \\
\hline Кировская область & ТОР «Белая Холуница», ТОР «Вятские Поляны» \\
\hline Нижегородская область & $\begin{array}{l}\text { ОЭЗ ППТ «Кулибин» (Дзержинск) ТОР «Володарск», } \\
\text { ТОР «Павловск», ТОР «Решетиха», ТОР «Саров» (ЗАТО) }\end{array}$ \\
\hline Оренбургская область & ТОР «Новотроицк», ТОР «Ясный» \\
\hline Пензенская область & ТОР «Заречный» (ЗАТО), ТОР «Сердобск» \\
\hline Самарская область & ОЭЗ ППТ в Тольятти, ТОР «Тольятти», ТОР «Чапаевск» \\
\hline Саратовская область & $\begin{array}{l}\text { ОЭЗ ТВТ «Саратов» (Саратов, Энгельсский и Балаковский } \\
\text { р-ны), ТОР «Петровск» }\end{array}$ \\
\hline Ульяновская область & $\begin{array}{l}\text { ПОЭЗ «Ульяновск» (Чердаклинский р-н) ТОР «Димитровград», } \\
\text { ТОР «Инза» }\end{array}$ \\
\hline \multicolumn{2}{|l|}{ Уральский фредеральный округ } \\
\hline Курганская область & ТОР «Варгаши», ТОР «Далматово», ТОР «Катайск» \\
\hline Свердловская область & $\begin{array}{l}\text { ОЭЗ ППТ «Титановая долина» (Екатеринбург, Сысерть и } \\
\text { Верхнесалдинский р-н) ТОР «Краснотурьинск», ТОР «Лесной» } \\
\text { (ЗАТО), ТОР «Новоуральск» (ЗАТО), ТОР «Верхняя Тура» }\end{array}$ \\
\hline Тюменская область & - \\
\hline Ханты-Мансийский АО & - \\
\hline Ямало-Ненецкий АО & Арктическая зона (вся территория) \\
\hline Челябинская область & $\begin{array}{l}\text { TОР «Бакал», ТОР «Верхний Уфалей», ТОР «Миасс», } \\
\text { TОР «Озерск» (ЗАТО), ТОР «Снежинск» (ЗАТО) }\end{array}$ \\
\hline \multicolumn{2}{|l|}{ Сибирский фредеральный округ } \\
\hline Республика Алтай & - \\
\hline Республика Тыва & - \\
\hline
\end{tabular}




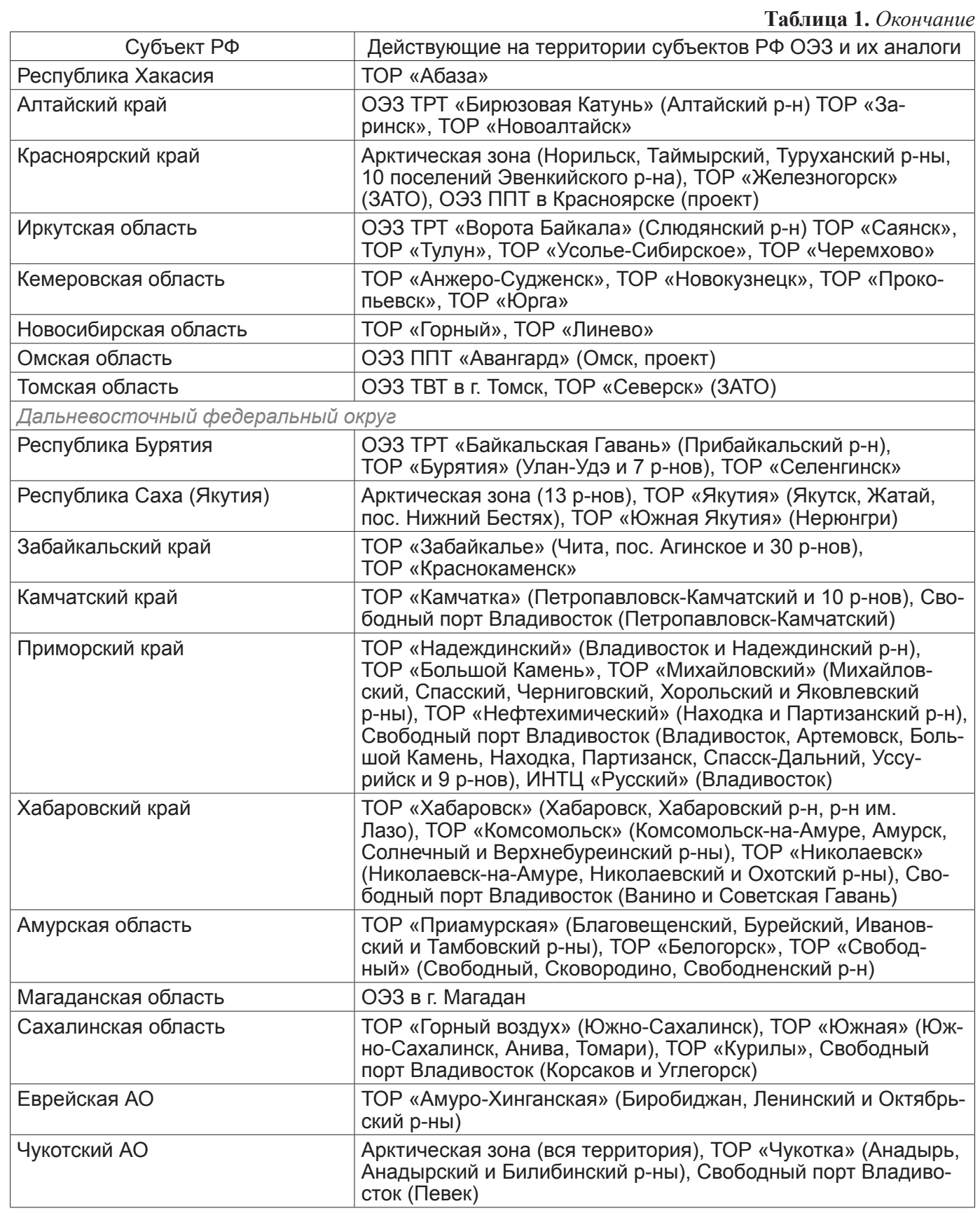

Источник: составлено автором на основе нормативно-правовых актов «КонсультантПлюс».

Примечания: под названными в таблице городами имеются в виду соответствующие им городские округа. ОЭз особая экономическая зона, ППТ - промышленно-производственного типа, ТВТ - технико-внедренческого типа, ТРТ - туристско-рекреационного типа, ПОЭЗ - портовая особая экономическая зона, ТОР - территория опережающего (социально-экономического) развития, ИНТЦ - инновационный научно-технологический центр, ЗАТО закрытое административно-территориальное образование, p-н - район.

По состоянию на декабрь 2020 г. в России создается 19 промышленно-производственных ОЭЗ, 7 технико-внедренческих ОЭЗ, 11 туристско-рекреационных ОЭЗ и 2 портовых ОЭЗ (всего 39 ОЭЗ, досрочно ликвидированные ОЭЗ в это число не входят),
22 ТОСЭР на Дальнем Востоке, 92 ТОСЭР в моногородах (включая 8 в ЗАТО) и 1 ТОСЭР в Арктике («Столица Арктики»), а также 4 ИНТЦ (см. табл. 1). По числу ОЭЗ и их аналогов Россия является одним из мировых лидеров [23]. 
При существующем многообразии ОЭЗ и их аналогов (ОЭЗ в понимании ЮНКТАД) неизбежно возникает вопрос, чем они отличаются друг от друга. Такие отличия есть по многим параметрам:

- по размерам территории, где вводится преференциальный режим: это могут быть и компактные участки территории (наименьшие размеры имеют технико-внедренческие ОЭЗ и ИНТЦ), и муниципальные образования (ТОСЭР в моногородах), и субъекты Федерации (Крым, Калининградская область) и даже огромная территория Арктической зоны РФ размером примерно в 5 млн кв. км. ОЭЗ и ТОСЭР могут состоять из нескольких участков, расположенных в разных частях регионов, причем размеры ОЭЗ/ТОСЭР могут увеличиваться уже после их создания;

- по формам финансирования инфраструктуры ОЭЗ и их аналогов, что отчасти связано с различиями в размерах их территории: вложения в инфраструктуру могут идти через государственные или федеральные целевые программы, субсидии резидентам на строительство объектов внешней инфраструктуры, взносы в уставный капитал госкомпаний. Федеральные вложения в инфраструктуру могут вообще не предусматриваться, например, с 2018 г. было создано несколько ОЭЗ, где инфраструктура строится за счет средств региональных бюджетов или даже частных инвесторов. В такой ситуации можно было бы сомневаться в выполнении одного из критериев ЮНКТАД, но речь идет именно об ОЭЗ как таковых;

- по форме управления территориями с преференциальными режимами - как специально созданными для этих целей управляющими компаниями, так и региональными или муниципальными органами власти (например, функции администрации ОЭЗ в Калининградской области выполняет одно из региональных министерств). Причем, как и в случае с финансированием инфраструктуры, по формам управления могут различаться не только разные типы территорий с преференциальными режимами, но и отдельные территории одного и того же типа;
- по спектру поддерживаемых с помощью преференций видов экономической деятельности: от только высокотехнологичных до большинства возможных (на Дальнем Востоке, в Арктике, Крыму);

- по наличию требований к резидентам ОЭЗ или их аналогов по минимальному объему капитальных вложений: от полного отсутствия таких требований до 120 млн руб. в производственных ОЭЗ и 50 или 150 млн руб. (в зависимости от вида деятельности) в Калининградской области. В Арктической зоне это 1 млн руб., в ТОСЭР на Дальнем Востоке - 500 тыс. руб., по СПВ 5 млн руб. В некоторых случаях (например, в ТОСЭР в моногородах) добавляются требования по минимальному числу новых рабочих мест;

- по набору административных преференций;

- по наличию или отсутствию режима свободной таможенной зоны: таковой применяется в ОЭЗ (за исключением туристических), СЭЗ в Крыму, ТОСЭР на Дальнем Востоке, в Арктике и ЗАТО, СПВ;

- по масштабам предоставляемых инвесторам налоговых льгот. Федеральное законодательство предусматривает во всех ОЭЗ и их аналогах предоставление льгот по региональной части налога на прибыль, региональному налогу на имущество организаций и местному земельному налогу, но конкретные параметры этих льгот, а также дополнительные льготы по региональному транспортному налогу устанавливаются самими региональными/местными властями, поэтому отличаются от территории к территории. По большинству территорий предусматривается также обнуление федеральной ставки налога на прибыль (исключение - промышленные ОЭЗ и туристические ОЭЗ за пределами Северного Кавказа). Льготы по налогу на добычу полезных ископаемых предусматриваются на Дальнем Востоке и в Арктике (но параметры льгот отличаются). В Крыму, Калининградской области, ТОСЭР и СПВ заметно снижаются тарифы страховых взно- 
сов - до 7,6\% (вместо стандартных $30 \%$ ), в Арктической зоне предполагается субсидирование 75\% страховых выплат. В «Сколково» и ИНТЦ на 10 лет возможно полное освобождение от уплаты налогов;

- по срокам действия преференциального режима - начиная от 10 лет у ТОСЭР в моногородах до неопределенных сроков в Арктике. ОЭЗ в Магаданской области закончит действовать в конце 2025 г.

При таком разнообразии различий в параметрах ОЭЗ и их аналогов неизбежно возникает вопрос, является ли оно оправданным или лишь создает чрезмерные сложности для инвесторов, которым надо разбираться во всех нюансах требований к резидентам и предоставляемым им льгот (мы указали различия в самом общем виде, вообще не разбирая, например, сроки действия налоговых льгот, административные преференции и т.д.). Дополнительной иллюстрацией такой сложности является то, что есть территории, где действует сразу несколько преференциальных режимов. Например, в Тольятти создана и промышленная ОЭЗ, и ТОСЭР; ТОСЭР оказались на территории Арктической зоны РФ; на Дальнем Востоке минимальны различия между ТОСЭР и Свободным портом Владивосток; на Чукотке теперь вообще три варианта преференциальных режимов (ТОСЭР, СПВ и Арктики).

На наш взгляд, причин множественности разных типов территорий с преференциальными режимами несколько. Одна из них ведомственная разобщенность - ОЭЗ и их аналоги курируются разными федеральными министерствами, которые разрабатывают и продвигают «свои» территории с преференциальными режимами [5].

Вторая причина - не всегда однозначно высокая результативность действующих преференциальных режимов и надежда чиновников на то, что новый режим окажется существенно лучше предыдущего. В этом отношении весьма показательна ситуация с утвержденной Правительством РФ в феврале 2019 г. Стратегией пространственного развития РФ на период до 2025 года (СПР). При разработке СПР проблема чрезмерной сложности системы ОЭЗ и их аналогов обсуждалась, в проекте СПР предусматривалось формирование единого механизма поддержки инвесторов, однако в итоговом документе говорится о создании нового механизма развития территорий (инвестиционных площадок) с особым режимом ведения предпринимательской деятельности. Причем всего лишь ради учета перспективных специализаций субъектов РФ и иных особенностей территорий, что вполне можно сделать путем корректировки действующих режимов ОЭЗ и их аналогов.

Третья и более-менее оправданная причина - это объективно существующие различия между регионами, где вводятся преференциальные режимы. Например, очевидно, что на Дальнем Востоке и в Арктике нельзя отказываться от поддержки добывающей промышленности, тогда как в большинстве остальных регионов вполне можно исходить из необходимости снижения сырьевого характера российской экономики и сырьевой сектор специально не поддерживать.

В этой связи как раз важно обратиться непосредственно к географии ОЭЗ и их аналогов (см. табл. 1). Очевидно, что самые выгодные для инвесторов преференциальные режимы созданы, прежде всего, для приоритетных геостратегических территорий России. Таковыми в СПР названы Дальневосточный и Северо-Кавказский федеральные округа, Крым, Калининградская область и Арктическая зона РФ. Как видим, исключением является Северный Кавказ: система преференциальных режимов сокращению отставания Северного Кавказа от среднероссийских показателей точно не способствует. Здесь нет общего для всего региона преференциального режима, доминируют туристические ОЭЗ с минимальными (по сравнению с другими режимами) преференциями для инвесторов, всего одна промышленная ОЭЗ и три ТОСЭР в моногородах, и такую ситуацию вряд ли можно назвать оправданной. В 2020 г., с упразднением Минкавказа России и передачей его полномочий в Минэкономразвития России, началось формирование новой федеральной политики в отношении Северного Кавказа, возможно, названное обстоятельство будет принято во внимание.

Анализ распределения ОЭЗ и их аналогов по субъектам РФ выявил те из них, где вообще нет федеральных территорий с преференциальными режимами (см. табл. 1), и большинство таких регионов относятся к числу наименее экономически развитых: 
Республики Алтай, Тыва, Адыгея, Калмыкия, Марий Эл (все они входят в перечень 10 регионов с низким уровнем социальноэкономического развития, для которых правительством утверждены индивидуальные программы их развития). Далеко не самая благоприятная экономическая ситуация также в Брянской и Курской областях.

Напротив, в целом ряде самых экономически благополучных субъектов РФ создано немало ОЭЗ и их аналогов. Так, в Москве действуют целый ряд льготных режимов для инновационной деятельности (характеризующиеся очень значимыми преференциями «Сколково» и ИНТЦ, а также технологическая ОЭЗ, изначально созданная в Зеленограде, но в апреле 2017 г. расширенная за счет площадки в районе Печатники - территории бывшего завода АЗЛК). Лидером по числу ОЭ3-3 промышленных и 2 технологическихявляется Московская область. В Поволжье выделяется Татарстан - 2 ОЭЗ и максимальное количество ТОСЭР в моногородах в одном регионе - 5. В целом прослеживается закономерность: чем выше уровень экономического развития субъекта РФ, значимее его экономический потенциал, тем больше в нем территорий с преференциальными режимами, хотя, конечно, есть и исключения. Например, очень слабо используется потенциал ОЭЗ и их аналогов в Санкт-Петербурге и Ленинградской области. Таким образом, созданные за пределами приоритетных геостратегических территорий ОЭЗ и их аналоги будут способствовать скорее нарастанию межрегиональных диспропорций, нежели их сокращению.

Добавим, что и в пределах Дальнего Востока прослеживается та же самая закономерность. Лидером по числу аналогов ОЭЗ является Приморский край, в силу своего экономико-географического положения являющийся одним из самых привлекательных для инвесторов дальневосточных регионов. Напротив, в Магаданской области, где сложно найти точки роста, не создано ни одной ТОСЭР, тогда как льготы в рамках действующего в регионе режима ОЭЗ менее масштабны (прежде всего, нет кардинального снижения ставок страховых взносов).

Причина возникновения подобной ситуации очевидна: в российском законодательстве нет требований увязывать создание ОЭЗ или их аналогов с уровнем социально- экономического развития регионов. Более того, если часть преференциальных режимов по их замыслу можно считать инструментами региональной политики (режимы для приоритетных геостратегических регионов, ТОСЭР в моногородах), то собственно ОЭЗ, «Сколково» и ИНТЦ задумывались как инструменты инвестиционной или инновационной политики и их создание предполагается там, где они могут быть наиболее эффективными. Хотя часть ОЭЗ создавали, руководствуясь все же необходимостью поддержки проблемных территорий: моногородов в Самарской и Свердловской областях, республик Северного Кавказа, отстающей по уровню экономического развития Псковской области.

Оценивать такую ситуацию можно неоднозначно. С одной стороны, создавать территории с преференциальными режимами, которые не привлекут инвесторов, бессмысленно, это пустая трата бюджетных ресурсов (пусть даже только на управленческие расходы). С другой стороны, необходимо решать задачу сокращения территориальных диспропорций, и преференциальные режимы для инвесторов - один из самых очевидных инструментов для этого. На наш взгляд, основная причина полного отсутствия результатов или низкой эффективности отдельных ОЭЗ или их аналогов - недостаточная благоприятность предлагавшихся инвесторам условий, причем как в части преференций, так и инфраструктурной обеспеченности. Особенно это справедливо в отношении туристических ОЭЗ [6]. Дополнительным фактором является явно недостаточная информированность предпринимателей о действующих в стране преференциальных режимах. Поэтому, на наш взгляд, нужно не отказываться от таковых в качестве инструмента региональной политики, а принимать более адекватные решения.

Выводы. Подводя итог проведенного анализа, важно, прежде всего, отметить чрезмерную сложность сложившейся в России системы территорий с преференциальными режимами (ОЭЗ и их аналогов), что отнюдь не способствует улучшению инвестиционного климата и ведет к снижению прозрачности федеральной инвестиционной политики. Идеальным решением проблемы, конечно, могла бы стать унификация всех действую- 
щих ОЭЗ и их аналогов - разработка единого закона о преференциальных режимах, однако такой сценарий маловероятен и очень сложен (прежние попытки успехом не увенчались [4]). Поэтому можно предложить более простое решение - создать полноценную государственную информационную систему, в рамках которой была бы сведена вся информация, причем детальная, по действующим в стране территориям с преференциальными режимами. Что не исключает внесение в действующие законы поправок, позволяющих, насколько это возможно, обеспечить большее единообразие в параметрах предоставляемых инвесторам преференций. Кроме того, не имеет смысла сохранять разные по степени благоприятности преференциальные режимы на одной и той же территории.

Включение в такую информационную систему географии действующих ОЭЗ и их аналогов позволит федеральным властям адекватнее оценивать вклад преференциаль- ных режимов в достижение целей федеральной политики пространственного развития. На сегодняшний день преференциальные режимы способствуют социально-экономическому развитию приоритетных геостратегических территорий, хотя есть исключение в виде Северного Кавказа. За пределами таких территорий созданные ОЭЗ и их аналоги будут скорее способствовать росту межрегиональных различий в уровне социально-экономического развития, нежели их сокращению. На наш взгляд, создавать ОЭЗ или их аналоги в проблемных регионах необходимо, но создаваемые для инвесторов условия должны быть достаточны для компенсации негативных факторов инвестиционной привлекательности таких территорий, и нельзя использовать единые подходы к оценке эффективности работы преференциальных режимов в регионах с объективно разным уровнем привлекательности для инвесторов (как это сейчас происходит с ОЭЗ).

\section{СПИСОК ЛИТЕРАТУРЫ}

1. Авдеев Ю.А. Свободный порт Владивосток - за и против // ЭКО. 2017. № 2. С. 5-26.

2. Гаврилова Н.М. Территории инновационного развития России // Гос. ун-т Минфина России. Финансовый журнал. 2012. № 4. С. 81-90.

3. Горбачева Н.В., Унтура Г.А. Оценка воздействия налоговых преференций на финансовые результаты высокотехнологического бизнеса в России // Финансы и кредит. 2015. № 36. С. 19-32.

4. Громова Е.А. Перспективы развития законодательства о территориях со специальным режимом экономической деятельности // Lex russica. 2020. T. 73. № 11. С. 9-20. DOI: 10.17803/17295920.2020.168.11.009-020.

5. Кузнецова О.В. О федеральной поддержке локализации инвестиций в России // Общество и экономика. 2016. № 3. С. 105-123.

6. Кузнецова О.В. Особые экономические зоны: эффективны или нет? // Пространственная экономика. 2016. № 4. C. 129-152. DOI: 10.14530/se.2016.4.129-152.

7. Ленчук Е.Б. Формирование инновационной инфраструктуры в российских регионах // Вестн. Ин-та экономики РАН. 2013. № 5. С. 76-91.

8. Леонов С.Н. Преференциальные режимы созданных локальных точек роста и их влияние на экономику Дальнего Востока // Эконом. и социал. перемены: факты, тенденции, прогноз. 2020. T. 13. № 3. C. 28-45. DOI: 10.15838/esc.2020.3.69.3.

9. Либак В.В. Оценка институтов развития бизнеса предпринимателями города Владивостока // Ars Administrandi (Искусство управления). 2019. Том 11, № 2. C. 237-266. DOI: 10.17072/22189173-2019-2-237-266.

10. Ломакина Н.В. Государственное стимулирование инвестиций в минерально-сырьевые проекты: дальневосточный вариант // Регионалистика. 2018. Т. 5. № 4. С. 14-23. DOI: 10.14530/ reg.2018.4.14.

11. Малкова Ю.В. К вопросу о необходимости создания зон с преференциальными налоговыми режимами с целью развития промышленных кластеров // Налоги и налогообложение. 2019. № 7. C. 1-18. DOI: 10.7256/2454-065X.2019.7.30481.

12. Микитчук В.П. Современные подходы к проблеме регулирования предпринимательской деятельности в условиях особой экономической зоны (на материалах ОЭЗ Магаданской области) // Экономика: вчера, сегодня, завтра. 2019. Том 9. № 3A. C. 506-516. DOI: 10.34670/ AR.2019.89.3.056.

13. Мотуренко С.М. Зоны территориального развития как новая форма развития предпринимательства // Труды Ин-та государства и права РАН. 2014. № 1. С. 178-189.

14. Ниязова М.В., Варавенко В.Е. Особые правовые режимы предпринимательства на Дальнем Востоке России: экономико-правовое исследование. Владивосток, 2018. 138 с.

15. Павлов П.В. Сравнительная характеристика законодательного регулирования различных видов особых экономических зон в Российской Федерации // Вестн. Финансовой академии. 2009. № 5. С. 33-38.

16. Пинская М.P. Свободная экономическая зона в Крыму: старые решения и новые возможности // Региональная экономика: теория и практика. 2015. № 44. С. 45-54. 
17. Прачева Е.В. Сравнение инструментов региональной политики: территории опережающего социально-экономического развития, особые экономические зоны, зоны территориального развития// Корпоративная экономика. 2018. № 3. С. 4-11.

18. Bost F. Special Economic Zones: methodological issues and definition // Transnational Corporations. 2019. Vol. 26. № 2. P. 141-153. DOI: 10.18356/948d2781-en.

19. Kuznetsov A. V., Kuznetsova O.V. The success and failure of Russian SEZs: some policy lessons /I Transnational Corporations. 2019. Vol. 26. № 2. P. 117-139. DOI: 10.18356/89dba835-en.

20. Kuznetsova A.L. Towards a stable and dynamic economy in the Kaliningrad region // Baltic Region. 2015. No. 3. P. 83-95. DOI: 10.5922/2079-8555-2015-3-7.

21. Narula R., Zhan J.X. Using Special Economic Zones to facilitate development: policy implications // Transnational Corporations. 2019. Vol 26. № 2. P. 141-153. DOI: 10.18356/72e19b3c-en.

22. Nilov K.N. The Special Economic Zone in the Kaliningrad Region: towards a more effective legal regime// Baltic Region. 2018. Vol. 10. № 4. P. 74-87. DOI: 10.5922/2079-8555-2018-4-5.

23. World Investment Report 2019. Special Economic Zones. UNCTAD, Geneva, 2019. 237 p.

Статья поступила в редакцию 15 декабря 2020 г.

Статья принята к публикации 29 декабря 2020 г.

\title{
Об авторе
}

Кузнецева Ольга Владимировна - главный научный сотрудник Федерального исследовательского центра «Информатика и управление» РАН; заведующий лабораторией региональной политики и региональных инвестиционных процессов Российского экономического университета имени Г.В. Плеханова; профессор МГУ имени М.В. Ломоносова.

\section{Для цитирования:}

Кузнецова О.В. География особых экономических зон и их аналогов в России // Региональные исследования. 2020. № 4. С. 19-31.

DOI: $10.5922 / 1994-5280-2020-4-2$

\section{Geography of Special Economic Zones and their analogues in Russia}

\author{
O.V. Kuznetsova ${ }^{1,2,3}$ \\ ${ }^{1}$ Federal Research Center "Informatics and Control" of the Russian Academy of Sciences, \\ Moscow, Russia \\ 2 Plekhanov Russian Economic University, Moscow, Russia \\ ${ }^{3}$ Lomonosov Moscow State University, geographical department, Moscow, Russia \\ e-mail: kouznetsova_olga@mail.ru
}

\begin{abstract}
The article suggests using the UNCTAD approach to the allocation of special economic zones, according to which SEZs can be considered as entities that meet three criteria: clearly defined boundaries of the zone territory, economic activity regime different from the national one, developed infrastructure. The article analyzes the geography of SEZs in Russia in such a broad sense. It is concluded that the Russian SEZ system and its analogues are unreasonably complex, and it is proposed to create a full-fledged state information system for territories with preferential regimes for investors, and to increase the uniformity of existing regulations. It is shown that at present preferential regimes contribute to the socioeconomic development of priority geostrategic territories (with the exception of the North Caucasus), but beyond their borders they rather contribute to the growth of interregional differences in the level of socio-economic development, rather than their reduction. it is proposed not to abandon the creation of SEZs and their analogues in problem regions, but to provide investors with sufficient favorable conditions and to differentiate approach to assessing the effectiveness of SEZs and their analogues in regions with objectively different levels of investment attractiveness.
\end{abstract}

Keywords: preferential regime, special economic zones, territories of advanced development, geostrategic territories, single-industry towns, investment policy, regional policy.

\section{REFERENCES}

1. Avdeev Yu.A. The free port of Vladivostok - pros and cons. EKO, 2017, no. 2, pp. 5-26. (In Russ.).

2. Gavrilova N.M. The regions of innovative development of Russia. Gosudarstvennyy Universitet Minfina Rossii. Finansovyy Zhurnal, 2012, no. 4, pp. 81-90. (In Russ.).

3. Gorbacheva N.V., Untura G.A. Assessing the impact of preferences on financial results of advanced technology business in Russia. Finansy i Kredit, 2015, no. 36, pp. 19-32. (In Russ.). 
4. Gromova E.A. Prospects of development of legislation on territories with special regime for business activity. Lex russica, 2020, vol. 73, no. 11, pp. 9-20. DOI: 10.17803/1729-5920.2020.168.11.009-020. (In Russ.).

5. Kuznetsova O.V. About federal support for investment localization in Russia. Obshchestvo i Ekonomika, 2016, no. 3, pp. 105-123. (In Russ.).

6. Kuznetsova O.V. Special economic zones: efficient or not? Prostranstvennaya Ekonomika, 2016, no. 4, pp. 129-152. DOI: 10.14530/se.2016.4.129-152. (In Russ.).

7. Lenchuk E.B. Formation of innovative infrastructure in the Russian regions. Vestnik Instituta Ekonomiki Rossiyskoy Akademii Nauk, 2013, no. 5, pp. 76-91. (In Russ.).

8. Leonov S.N. Preferential regimes of established local growth points and its impact on the economy of the Far East. Ekonomicheskie i Sotsial'nye Peremeny: Fakty, Tendentsii, Prognoz. 2020, vol. 13, no. 3, pp. 28-45. DOI: 10.15838/esc.2020.3.69.3 (in Russ.)

9. Libak V.V. Analysis of development institutions perception by the entrepreneurs of Vladivostok. Ars Administrandi, 2019, vol. 11, no. 2, pp. 237-266. DOI: 10.17072/2218-9173-2019-2-237-266. (In Russ.).

10. Lomakina N.V. Government promotion of investment in mineral and raw materials projects: Far Eastern case. Regionalistica, 2018, vol. 5, no. 4, pp. 14-23. DOI: 10.14530/reg.2018.4.14 (In Russ.).

11. Malkova Yu.V. To the question on the need for creation of zones with preferential tax regimes for the development of industrial clusters. Nalogi $i$ Nalogooblozhenie, 2019, no. 7, pp. 1-18. DOI: 10.7256/2454-065X.2019.7.30481. (In Russ.).

12. Mikitchuk V.P. Modern approaches to the problem of regulation of business activities in a Special Economic Zone (the example of Magadan region)]. Ekonomika: vchera, segodnya, zavtra, vol. 9, no. 3A, pp. 506-516. DOI: 10.34670/AR.2019.89.3.056. (In Russ.).

13. Moturenko S.M. Areas of territorial development as a new form of enterprise development. Trudy Instituta Gosudarstva i Prava Rossiyskoy Akademii Nauk, 2014, no. 1, pp. 178-189. (In Russ.).

14. Niyazova M.V., Varavenko V.E. Osobye pravovye rezhimy predprinimatel'stva na Dal'nem Vostoke Rossii: ekonomiko-pravovoe issledovanie [The special legal regimes for entrepreneurial business on the Russian Far East: economic and legal research]. Vladivostok, 2019, 138 p. (In Russ.).

15. Pavlov P.V. Comparative characteristic of legislative control for different types of special economic zones in Russian Federation. Vestnik Finansovoy Akademii, 2009, no. 5, pp. 33-38. (In Russ.).

16. Pinskaya M.R. Free economic zone in Crimea: old solutions and new opportunities. Regional'naya Ekonomika: Teoriya i Praktika, 2015, no. 44, pp. 45-54 (in Russ.).

17. Pracheva E.V. Comparison of regional policy instruments: the territory of advancing socio-economic development, the special economic zone, the zone of territorial development. Korporativnaya Ekonomika, 2018, no. 3, pp. 4-11. (In Russ.).

18. Bost F. Special economic zones: methodological issues and definition. Transnational Corporations, 2019, vol. 26, no. 2, pp. 141-153. DOI: 10.18356/948d2781-en.

19. Kuznetsov A.V., Kuznetsova O.V. The success and failure of Russian SEZs: some policy lessons. Transnational Corporations. 2019. Vol. 26, no. 2. pp. 117-139. DOI: 10.18356/89dba835-en.

20. Kuznetsova A.L. Towards a stable and dynamic economy in the Kaliningrad region. Baltic Region, 2015, no. 3, pp. 83-95. DOI: 10.5922/2079-8555-2015-3-7.

21. Narula R., Zhan J.X. Using special economic zones to facilitate development: policy implications. Transnational Corporations, 2019, vol. 26, no. 2, pp. 141-153. DOI: 10.18356/72e19b3c-en.

22. Nilov K.N. The Special economic zone in the Kaliningrad region: towards a more effective legal regime. Baltic Region, 2018, vol. 10, no. 4, pp. 74-87. DOI: 10.5922/2079-8555-2018-4-5.

23. World Investment Report 2019. Special Economic Zones / UNCTAD, Geneva, 2019. 237 p. 